\title{
Root Biomass Estimation in Natural and Planted Mangrove
}

\author{
Nasir Sudirman, Terry Louise Kepel*, Restu Nur Afi Ati, Mariska A. Kusumaningtyas, Hadiwijaya Lesmana Salim \\ Marine Research Center, Agency for Marine and Fisheries Research and Human Resources
}

\begin{abstract}
Belowground root biomass plays an essential role in the mangrove ecosystem as potential carbon storage, nutrient gain, or sediment accumulation yet is still overlooked. Therefore, estimation of root biomass is necessary. The objective was to determine and compare the belowground root biomass at the natural and planted mangrove ecosystem. We also measured the forest structure and the aboveground biomass. This study was conducted at four stations in Pramuka Island, Pari Island, Rambut Island (2 stations), Seribu Islands, Jakarta. The first island represented planted mangroves, whereas the latter two as natural stems. Rhizophora stylosa was the dominant species in three stations except for Rambut Island 2 that dominated by Ceriops Tagal. Stand densities were $2730 \pm 5$ stems ha- $1,1733 \pm 5$ stems ha- $1,1311 \pm 2$ stems ha-1, and $1300 \pm 2$ stems ha- 1 for Pramuka Island, Pari Island, Rambut Island 1 and 2 . The highest pile density was counted in Rambut Island 2 for $1612 \pm 8$ stems ha- 1 and the lowest in Pramuka Island (780 \pm 5 stems ha-1). The aboveground biomass was estimated as follows $109.13 \pm 11.91 \mathrm{Mg}$ ha-1 in Pari Island, $89.45 \pm 19.53$ in Rambut Island 2, 68.41 $\pm 17.12 \mathrm{Mg}$ ha-1 in Rambut Island 1 , and $14.05 \pm 5.74 \mathrm{Mg}$ ha- 1 in Pramuka Island. Belowground root biomass in planted mangrove Pramuka Island (3.63 $\pm 0.82 \mathrm{Mg}$ ha-1) and the other two natural mangroves Pari Island $(6.56 \pm 0.47 \mathrm{Mg}$ ha- 1$)$ and Rambut Island 1 ( $7.17 \pm 0.81 \mathrm{Mg}$ ha1 ), were similar except for Rambut Island $2(49.23 \pm 6.77 \mathrm{Mg}$ ha-1). The contribution of root biomass ranges from $6-24 \%$ of the total biomass of mangrove trees, whereas the fine roots $(<2 \mathrm{~mm})$ biomass occurred 28 $74 \%$ in the entire root biomass. The results confirm the high contribution of belowground root biomass to the total biomass pool and the importance of maintaining the planted mangrove as a part of ecosystem rehabilitation.
\end{abstract}

Keywords: Belowground, Fine Root, Seribu Island.

\section{Introduction}

Mangrove roots play essential roles. Despite supporting the trees, the roots above the ground become a distinguishing feature among the mangrove family group. Mangrove also has a cable root system that spreads laterally in the sediment [1]. From these lateral roots spread smaller roots that grow vertically downwards. This root system is shallow, generally less than 2 meters, and closely related to the mangrove strategy to adapt to extreme environmental conditions of high salinity, anoxia, and inundation [1], [2]. In addition to the above biomass, roots (belowground biomass) are an essential part of the carbon budget ([3], [4]). The root is a source of organic $\mathrm{C}$ in sediments. Roots accounted for $5-25 \%$ of the total $\mathrm{C}$ present in sediments, became a significant source of organic $\mathrm{C}(<2 \mathrm{~mm})$ [5], [6].

The Estimation of carbon storage concentrates on calculating the aboveground biomass using general and species-specific allometric equations. In comparison, the belowground biomass estimation was carried out based on the general allometric equation [7]. One of the few studies that estimate belowground root biomass in Indonesia was done by Sidik et al. [8] in natural and restored mangroves. This study aimed to determine and compare the belowground root biomass at the natural and planted mangrove ecosystem. In addition, we also measured the forest structure and the aboveground biomass.

\section{Methods \\ 2.1 Study site}

The study sites for mangrove ecosystems locates on three islands in the Thousand Islands-Jakarta, namely Pramuka Island, Pari Island, and Rambut Island. Pramuka Island is the capital of the Thousand Islands Regency. Mostly planted on Pramuka Island, the mangroves are found on the south, the north, and the east sides of the island. Pari Island locates adjacent to Kongsi island, Tikus Island, Burung Island, and Tengah Island. Around the island, there are fringing reefs with flat sand with a reef slope to a depth of $20 \mathrm{~m}$ [9]. Mangroves on Pari Island grow in the west, east, and north of the island. However, the most extensive mangrove cover is in the north.

Rambut Island is a wildlife reserve based on the Decree of the Minister of Forestry No. 275/Kpts-II/1999 dated May 7, 1999, that protects both local and migratory birds that live on this island. In addition, this area was conserved under the Ramsar Convention (The Convention on Wetlands of International Importance, especially as Waterfowl Habitat), an international convention for conservation and sustainable use of

\footnotetext{
* Corresponding author: kepelterry@yahoo.com
} 
wetlands. About 56 bird species on Rambut Island, 18 species for waterbird groups and 38 non-waterbird species [10].

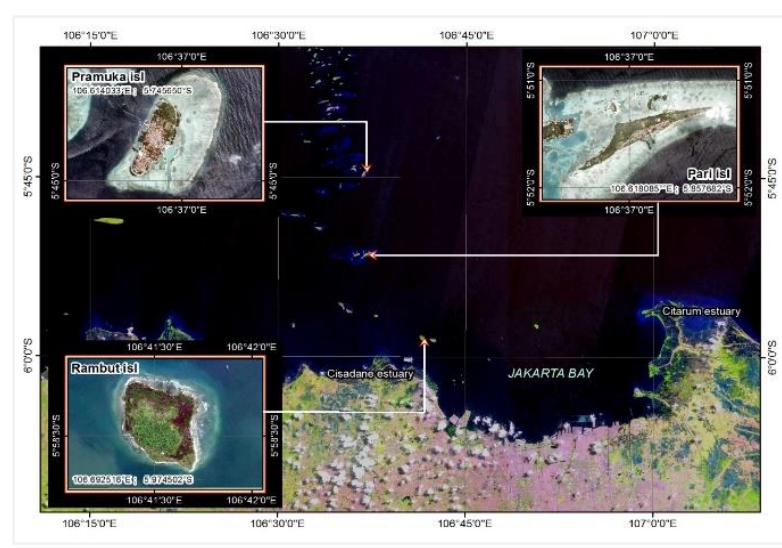

Figure 1. Study Site

\subsection{Field Sampling}

Carried out at four stations, the sampling was taken in Pramuka Island, Pari Island, and Rambut Island. Measurement and sampling for vegetation and carbon following an internationally recognized procedure ([11], [12]). Circular plots (7 $\mathrm{m}$ in diameter) were placed in every $25 \mathrm{~m}$ starting from the $0 \mathrm{~m}$ along a line transects point. Therefore, there are six circular plots on a $125 \mathrm{~m}$ line transect. The entire plots are 21 plots $(3$ plots at Pramuka Island, six plots at Pari island, and 12 plots at Rambut island) with about $808 \mathrm{~m} 2$. In each field, the identification of mangrove species, the measurement of tree circumference $(\mathrm{DBH})$, and the number of trees counting were done. In addition, environmental conditions were measured, such as temperature, salinity (using handheld refractometer), and $\mathrm{pH}$ (using $\mathrm{pH}$-meter ATC).

\subsection{Estimation of Belowground Root Biomass}

Roots were taken in all measurement plots four times, each using a four-inch PVC pipe. They were immediately separated from the sediment using a sieve in the field, cleaned, and stored in a plastic bag until further analysis in the laboratory. Clean roots were separated according to size with the following classification: fine $(\mathrm{F})<2 \mathrm{~mm}$, small (S) 2-5, medium (M) 5-10, and large (L) $>10 \mathrm{~mm}$ [13]. In this study, there was no separation between dead roots and live roots. Therefore, all the taken roots, both live and dead, were counted as part of the root biomass. In addition, the roots were not separated by depth because the average sediment depth in all sites was only $30 \mathrm{~cm}$ deep. Roots that are below $45 \mathrm{~cm}$ are classified as surface roots (shallow root zone) [14]. The samples were dried using an oven in the laboratory at a temperature of $70^{\circ} \mathrm{C}$ to constant weight. The dry weight is then calculated as biomass and converted into the area.

\subsection{Estimation of Aboveground Biomass}

The aboveground biomass was calculated by using a species-specific allometric equation. In addition, we used measured DBH and published wood density.

\subsection{Data Analysis}

Variations in fine root biomass were analyzed using one-way ANOVA to see differences between study sites. Post-hoc analysis used Tukey's test $(\mathrm{P}<0.05)$. Previously, all data were analyzed by using the Kolmogorov-Smirnov [15] to see its normality.

\section{Results and Discussion \\ 3.1 Characteristics of Mangrove Ecosystem}

The mangrove characteristics in the study site are slightly different (Table 1). On Pramuka Island, Rhizophora Stylosa was the only species found. Following other studies, R. Stylosa is the best species planted in Pramuka Island [16][17]. The dominant mangrove species in Pari Island are R. Stylosa and R. mucronata. However, other species such as R. Apiculata, A. marina, and S. alba also grow [18]. The mangrove area in Pari Island has decreased by $31.46 \%$ from its original location between 1999 - 2006 [19]. The condition may be due to the ongoing abrasion process on the west and east sides of Pari and Kongsi Islands in 1913-1999 [20].

Three mangrove species were identified as $\mathrm{R}$. Stylosa, R. Mucronata, and C. Tagal during data collection on Rambut Island. However, more species live on Rambut Island than that number. Outside the transect, Xylocarpus Mollucensis, R. Apiculata, Avicennia Marina, and Bruguiera Gymnorhiza were identified. The other species found previously were Avicennia Alba, Avicennia Marina, Avicennia Officinalis, Excoecaria Agallocha, Lumnitzera Racemosa, Pemphis Acidula, Sonneratia Alba, and X. Granatum [21],[22]. Among those, three species were not identified in the current study, possibly due to community changes. The community changes recognized during 1977-2002 due to solid waste and oil pollution [21]. Furthermore, tree mortality on Rambut Island was found in the current study.

The mangrove community on Rambut Island is in a closed area because the area surrounds by mounds of sediment (sand) that block the entry of seawater into the mangrove area. However, the mangrove area is always inundated by the seawater at high tide. Seawater enters through the opening (inlet) in the northern part of the island. The incoming seawater then flows through natural creeks in the west and east of the island. In the western region, there is a shallow natural brackish water lake. In the north, it tends to be overgrown by Rhizophora species, and further south, it tends to be diverse. On the east side, we can find the planted mangroves.

The highest density of mangrove trees was on Pramuka Island $(2730 \pm 5)$, followed by Pari Island (1733 \pm 5$)$, Rambut Island $1(1311 \pm 2)$, and Rambut Island $2(1300 \pm 2)$. The high density on Pramuka Island is because the current research location is in a mangrove rehabilitation area where there are tightly planted mangrove seedlings. Mangroves seedlings planted in clusters. Each cluster was 5 meters long and 3 meters wide, where each consisted of 600 seedlings with a distance of about 1 meter from each other [17].

In contrast to tree density, the sapling density level on Rambut Island ( $1 \& 2$ ) was higher, reaching more 
than 1000 individuals ha- 1 than the other two islands. Tree density positively correlates with canopy closure, where a thicker and larger canopy would block seedlings and saplings from the sunlight needed for growth. Light and nutrients are the limiting factors for the seedling to survive and recruit to the sapling stage [23]. Another factor that can account for is space competition. With a lower tree density, Rambut Island provides more space for the sapling to grow.

The highest basal mangrove area is on Rambut Island 2, Pari Island, Rambut Island 1, and Pramuka Island. The average tree stem diameter was found on Pari Island $(8.01 \mathrm{~cm})$, Rambut Island $2(7.53 \mathrm{~cm})$, Rambut Island 1 (5.79 cm) and Pramuka Island (4.06).

Table 1. F Characteristics of the Mangrove Ecosystem $( \pm \mathrm{SE})$

\begin{tabular}{|c|c|c|c|c|}
\hline Parameter & Pramuka & Pari & $\begin{array}{c}\text { Rambut } \\
1\end{array}$ & $\begin{array}{c}\text { Rambut } \\
2\end{array}$ \\
\hline Status & Planted & Natural & $\begin{array}{l}\text { Natural, } \\
\text { Wildlife } \\
\text { Reserve }\end{array}$ & $\begin{array}{l}\text { Natural, } \\
\text { Wildlife } \\
\text { Reserve }\end{array}$ \\
\hline $\begin{array}{l}\text { Dominant } \\
\text { Species }\end{array}$ & $\begin{array}{c}R . \\
\text { Stylosa }\end{array}$ & $\begin{array}{c}R . \\
\text { Stylosa }\end{array}$ & $\begin{array}{c}R . \\
\text { Stylosa }\end{array}$ & C. Tagal \\
\hline $\begin{array}{c}\text { Tree } \\
\text { Density } \\
(\text { stems ha } \\
1 \text { ') }\end{array}$ & $2730 \pm 5$ & $1733 \pm 5$ & $1311 \pm 2$ & $1300 \pm 2$ \\
\hline $\begin{array}{l}\text { Sapling } \\
\text { Density } \\
\text { (stems ha- } \\
1 \text { ) }\end{array}$ & $780 \pm 5$ & $195 \pm 1$ & $1040 \pm 5$ & $1612 \pm 8$ \\
\hline $\begin{array}{l}\text { Basal area } \\
\left(\mathrm{m}^{2} \mathrm{ha}^{-1}\right)\end{array}$ & $\begin{array}{c}0.17 \pm 0.0 \\
5\end{array}$ & $\begin{array}{c}1.84 \pm 0 \\
43\end{array}$ & $\begin{array}{c}1.14 \pm 0.2 \\
4\end{array}$ & $\begin{array}{c}2.01 \pm 0.4 \\
4\end{array}$ \\
\hline $\begin{array}{l}\text { DBH } \\
\text { Average } \\
(\mathrm{cm})(\min \\
-\max )\end{array}$ & $\begin{array}{c}4.06 \\
(1.59- \\
7.32)\end{array}$ & $\begin{array}{c}8.01 \\
(1.91- \\
26.75)\end{array}$ & $\begin{array}{c}5.79 \\
(0.96- \\
22.61)\end{array}$ & $\begin{array}{c}7.53 \\
(0.32- \\
21.02)\end{array}$ \\
\hline $\begin{array}{l}\text { Abovegro } \\
\text { und } \\
\text { Biomass } \\
\left(\mathrm{Mg} \mathrm{ha}^{-1}\right)\end{array}$ & $\begin{array}{c}14.05 \pm 5 . \\
74\end{array}$ & $\begin{array}{c}109.13 \pm \\
11.91\end{array}$ & $\begin{array}{c}68.41 \pm 17 \\
.12\end{array}$ & $\begin{array}{c}89.45 \pm 19 \\
.53\end{array}$ \\
\hline $\begin{array}{l}\text { Belowgro } \\
\text { und Root } \\
\text { Biomass } \\
\left(\mathrm{Mg} \mathrm{ha}^{-1}\right)\end{array}$ & $\begin{array}{c}3.63 \pm 0.8 \\
2\end{array}$ & $\begin{array}{c}6.56 \pm 0 . \\
47\end{array}$ & $\begin{array}{c}7.17 \pm 0.8 \\
1\end{array}$ & $\begin{array}{c}49.23 \pm 6 \\
77\end{array}$ \\
\hline Salinity & 30 & 31 & 40.5 & 41 \\
\hline $\mathrm{pH}$ & 7.3 & 6.7 & 4.8 & 8 \\
\hline
\end{tabular}

\subsection{Aboveground and Belowground Root Biomass}

Aboveground biomass was estimated as follows 14.05 $\pm 5.74 \mathrm{Mg}$ ha-1 at Pramuka Island, 109.13 \pm 11.91 Mg ha- 1 at Pari Island, 68.41 $\pm 17.12 \mathrm{Mg}$ ha- 1 at Rambut Island 1, and $89.45 \pm 19.53 \mathrm{Mg}$ ha-1 at Rambut Island 2 . The highest biomass was in Pari Island, where the highest tree DBH was on average measure. Despite the highest tree density, Pramuka Island has the lowest aboveground biomass.

The results of belowground root biomass showed that the average density in Rambut Island 2 was the highest (49.23 $\pm 6.77 \mathrm{Mg}$ ha-1), followed by Rambut
Island 1 (7.17 $\pm 0.81 \mathrm{Mg}$ ha-1), Pari Island (6.56 \pm 0.47 $\mathrm{Mg}$ ha-1), and Pramuka Island (3.63 $\pm 0.82 \mathrm{Mg}$ ha-1) (Fig.2). Current results are comparable to root biomass in Micronesia [24] but lower than in Bali and Australia [8], [25]. However, the root biomass in Rambut Island 2 is comparable to the 8 -years restored mangrove. The condition may happen due to shallow sediment depth in all study areas that limit deeper root expansion.

Statistically, there was a significant difference in root biomass in Pulau Rambut 2, whereas there is no root biomass difference found in the other three locations. Thus, the condition indicates that planted mangrove growth could have potential belowground root biomass as nature mangrove. Belowground root biomass contributed 6-24\% of the total mangrove tree biomass (Fig.2). The highest contribution was in Rambut Island 2 , about $24 \%$, close to Pramuka Island $(21 \%)$. Pari Island and Rambut Island 2 share not considerably biomass account for $6 \%$ and $10 \%$ accordingly.

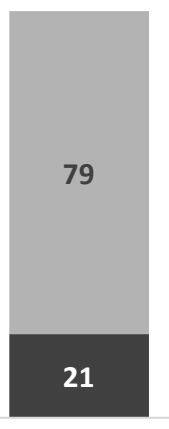

Pramuka

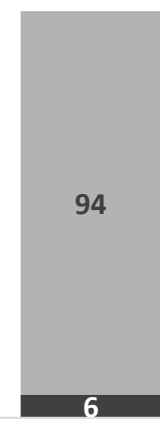

Pari

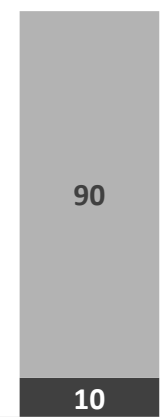

Rambut-1

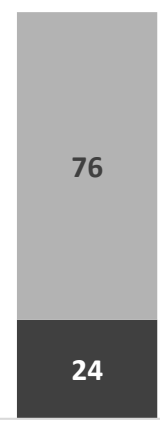

Rambut-2
- Belowground Root Aboveground

Figure. 2. Composition aboveground and belowground root biomass $(\%)$

\subsection{Composition of Root Biomass Class Size}

Figure 3 shows the proportion of root biomass based on size. The composition of medium root size (59\%) is dominant in Pramuka Island compared to refined and small size classes. In Pari Island, the weight of the large core reached $54 \%$ of the total root $(3.54 \mathrm{Mg}$ ha- 1$)$. The high proportion of large size was also in Pulau Rambut 1. Unlike the other three sites, fine-sized roots dominate $74 \%$ of Pulau Rambut 2.

Compared to other sizes, fine-sized roots occupy approximately one-third of the total biomass in all sites, accounting for $1.17 \mathrm{Mg}$ ha-1 at Pramuka Island, $1.85 \mathrm{Mg}$ ha- 1 at Pari Island, and $2.55 \mathrm{Mg}$ ha- 1 at Rambut Island 1 and $36.24 \mathrm{Mg}$ ha-1 at Rambut Island 2. Large-sized root was found at sites Pari Island (3.54 Mg ha-1), Rambut Island 1 (3.02 Mg ha-1), and Rambut Island 2 (2.14 Mg ha-1). Small-sized roots appeared in the lowest proportion from $2-15 \%$ of the total weight. 


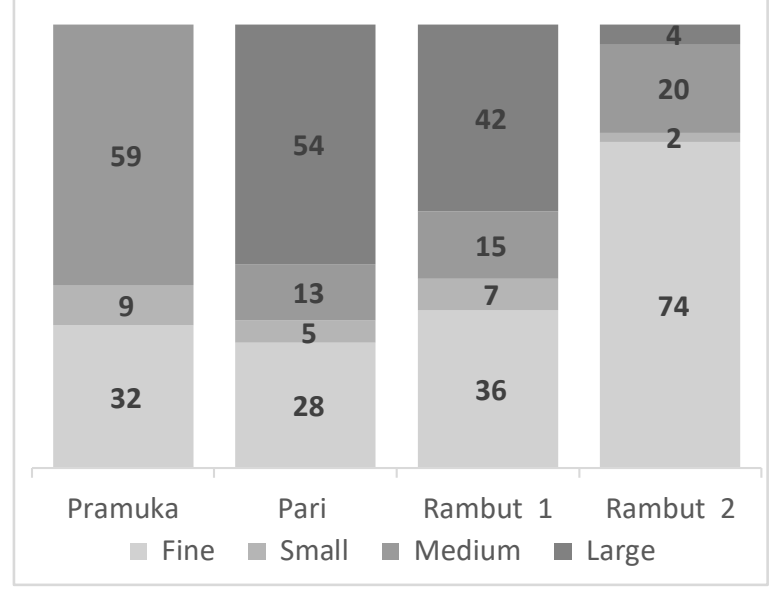

Fig. 3. Composition of root biomass class size (\%)

\section{Conclusion}

This study depicts a vital contribution of belowground root biomass to the total biomass of mangrove ecosystems in natural and planted areas. The composition of belowground root to aboveground biomass varies between 6-24\%. The highest biomass was from Rambut-2 accounted for 49.23 $\pm 6.77 \mathrm{Mg}$ ha-1. Meanwhile, fine-sized sources give the highest contribution to the total belowground root biomass among other class sizes. The highest contribution of the fine-sized source was $74 \%$ or $36.24 \mathrm{Mg}$ ha-1. Planted mangrove in Pramuka Island shows relatively lower biomass yet is comparable to the natural ones in Pari Island and Rambut Island 1. Therefore, this confirms the importance of maintaining mangrove planted areas.

\section{Acknowledgement}

The Authors thank The Natural Resources Conservation Center (BKSDA) - DKI Jakarta for the permit to research in the Rambut Island conservation area. The Authors also thank Sujatmiko Bayu Adi for his assistance during the field survey. This study is part of Blue Carbon Research in the Marine Research Center, Agency of Research and Human Resource, The Ministry of Marine Affairs and Fisheries, Republic of Indonesia. NS and TLK are the prominent authors of the paper. All authors also discussed and commented on the manuscript.

\section{References}

1. Peter Saenger, Mangrove Ecology, Silviculture and Conservation (2002).

2. D. M. Alongi, N. a. de Carvalho, A. L. Amaral, A. da Costa, L. Trott, and F. Tirendi, Biogeochemistry 109, 151 (2012).

3. F. Tamooh, M. Huxham, M. Karachi, M. Mencuccini, J. G. Kairo, and B. Kirui, Forest Ecology and Management 256, 1290 (2008).

4. A. I. Robertson and D. M. Alongi, Oecologia 180, 841 (2016).

5. D. C. Donato, J. B. Kauffman, D. Murdiyarso, S. Kurnianto, M. Stidham, and M. Kanninen, Nature Geoscience 4, 293 (2011).

6. X. Ouyang, S. Y. Lee, and R. M. Connolly, EarthScience Reviews 166, 53 (2017).
7. A. Komiyama, S. Poungparn, and S. Kato, Journal of Tropical Ecology 21, 471 (2005).

8. F. Sidik, M. Fernanda Adame, and C. E. Lovelock, Journal of the Indian Ocean Region 15, 177 (2019).

9. B. E. Brown and Suharsono, Coral Reefs 8, 163 (1990).

10. H. S. dan S. N. H. Suraji., N. Rasyid., A. S. H. Kenyo., A. R. Jannah., D. R. Wulandari., M. Saefudin., M. Ashari., R. Widiastutik., T. Kuhaja., E. Juliyanto., Y. A. Afandi., B. Wiyono., Profil Kawasan Konservasi DKI Jakarta (Direktorat Konservasi Kawasan dan Jenis Ikan, Direktorat Jenderal Kelautan, Pesisir dan Pulau-Pulau Kecil, Kementerian Kelautan dan Perikanan, Jakarta, 2015).

11. J. Kauffman and D. Donato, Center for International Forestry Working pa, 11 (2012).

12. M. (Eds. ). Howard, J., Hoyt, S., Isensee, K., Pidgeon, E., \& Telszewski, Book Conservati, (2014).

13. A. Komiyama, K. Ogino, S. Aksornkoae, and S. Sabhasri, Journal of Tropical Ecology 3, 97 (1987).

14. E. Castañeda-Moya, R. R. Twilley, V. H. RiveraMonroy, B. D. Marx, C. Coronado-Molina, and S. M. L. Ewe, Ecosystems 14, 1178 (2011).

15. S. Santoso, Statistik Multivariat Dengan SPSS (PT Elex Media Komputindo, Jakarta, 2017).

16. S. K. Putra, Aditya Cahya; Anggoro, SAINTEK PERIKANAN : Indonesian Journal of Fisheries Science and Technology 10, 91 (2015).

17. A. Haryanto, (2013).

18. Y. I. Suyadi; Ulumudin and R. Vebriansyah, Berita Biologi 12, 249 (2013).

19. G. Saefurahman, Thesis, Institut Pertanian Bogor (2008).

20. A. R. Farhan and S. Lim, Ocean and Coastal Management 65, 1 (2012).

21. O. Onrizal and C. Kusuma, Peronema Forestry Science J 2, (2006).

22. N. Santoso, Media Konservasi 10, 7 (2005).

23. P. J. Clarke and W. G. Allaway, Oecologia 93, 548 (1993).

24. N. Cormier, R. R. Twilley, K. C. Ewel, and K. W. Krauss, Hydrobiologia 750, 69 (2015).

25. K. Rogers, N. Saintilan, and D. Cahoon, Wetland Ecology and Management 13, 587 (2005). 